\title{
The academic plagiarism and its punishments - a review
}

\author{
Roberto G. S. Berlinck \\ Instituto de Química de São Carlos, Universidade de São Paulo, Brazil.
}

\begin{abstract}
Currently there is an increase in the occurrence of plagiarism in varied types of academic texts. Therefore, in agreement with the Brazilian Coordination of Improvement of Higher Education Personnel (CAPES) policies, Brazilian higher education institutions should establish guidelines for the detection and inhibition of academic plagiarism. However, the notion of plagiarism is extremely complex, since the ability of textual construction acquired during education is also developed using others' words. Thus, it is necessary to better know the concept of plagiarism and its implications, as well as the consequences of plagiarism and the punishments that may result from it. Consequently, rules and policies to be established will be better founded in order to address the problem of plagiarism in academic texts in a comprehensive and consistent way, not only to inhibit plagiarism but also to promote education on how is possible to create texts in an original fashion.
\end{abstract}

Revista Brasileira de Farmacognosia Brazilian Journal of Pharmacognosy 21(3): 365-372, May./Jun. 2011

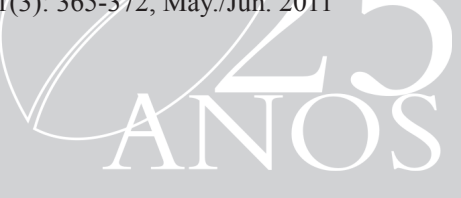

\section{Opinion}

Received 8 Apr 2011

Accepted 6 May 2011

Available online 10 Jun 2011

Keywords: authorship intertextuality plagiarism textual construction

ISSN 0102-695X doi: 10.1590/S0102-695X2011005000099

\section{Introduction}

In a recent statement to the academic community, the Brazilian Coordination of Higher Education Personnel (CAPES) recommended that higher education institutions should promote awareness about plagiarism when documents such as theses, monographs, articles and other texts that characterize the formulation of new concepts (CAPES, 2011). The CAPES statement is welcome and extremely important, considering the general increasing occurrence of plagiarism (Anonymous, 2011). Plagiarism has come to occupy a greater space in society, probably due to the access to electronic documents. For example, chemistry articles originally published in a peer-reviewed journal (Kuchler \& Silva, 1999; Dallago et al., 2005) have been later reported as copied into another journal (Garcia, 2009). Copies of dissertations and doctoral theses were notified in the Jornal da Ciência (Anonymous, 2009a). Also, a prosecutor of the Federal District admitted having copied fragments of another previously presented dissertation at the University of São Paulo (Stanisci, 2011). Another case of plagiarism between colleagues at the Institute of Physics, University of São Paulo has also been reported in the media (Garcia, 2008). Previous cases such as these are also common, and illustrate how the practice of plagiarism may be widespread both in Brazilian academia and society
(Anonymous, 2009b; Bottmann, 2011; Rodrigues, 2008), but obviously is not restricted to Brazil (Butler, 2010). Considering these facts, the CAPES' guideline is relevant and imperative. However, plagiarism is only a small fraction of fraudulent practices, such as copies, inadequate referencing, citation of texts fragments, and even cheating when screening tests, activities reports and many other documents are written in the context of academic activities.

The purpose of this article is to review ways of plagiarism in the preparation of texts, as well as the reasons why we observe plagiarism, punishment approaches that are adopted when plagiarism is discovered as well as the promotion of initiatives that result in the prevention of plagiarism and other forms of inappropriate text writing.

\section{Definitions of plagiarism}

Although some dictionaries treat the etymology of the word plagiarism as coming from the Latin, plagiarius (hijacker), Skandalakis \& Mirilas (2004) argue that the word originated from the Greek plagios (obliquity, in the sense that whom presents a skewed moral). According to the Ethics Committee of Editors of the British Journal of Surgery, "[...] Plagiarism ranges from the unreferenced use of others' published and unpublished ideas, including research grant 
applications to submission under "new" authorship of a complete paper, sometimes in a different language. It may occur at any stage of planning, research, writing, or publication: It applies to print and electronic versions" (Skandalakis \& Mirilas, 2004). Maurer et al. (2006) list the following activities that result in plagiarism:

“a) turning in someone else's work as your own; b) copying words or ideas from someone else without giving credit; c) failing to put a quotation in quotation marks; d) giving incorrect information about the source of a quotation; e) changing words but copying the sentence structure of a source without giving credit; f) copying so many words or ideas from a source that it makes up the majority of your work, whether you give credit or not."

Although these definitions are clear, the borrowed word has always been frequently used throughout the history of society. From childhood we learn to speak, read and write using the others' words. Many times our words are actually the others' words. During the literacy and learning of textual construction, reproduction is frequently used through exercises of memorization and copying. Moreover, many ideas and "sayings" are so widely used that it is virtually impossible to assign authorship to them. The way language is used and recycled makes plagiarism an extremely complex issue (Pennycook, 1996).

According to the historical account presented by Pennycook (1996), Aristotle and Plato believed that imagination was much more a reproductive than a productive activity. Until the Renaissance, the practice of imitation was widely used in the arts. The creation of original texts began to be valued only after the European Enlightenment movement. The quality of a text was intrinsically related to his former owner, a source of truth and authority, and the verbatim copying was considered a socially acceptable practice, widely used and represented the good quality of a text. Such practices also had recognition in some East Asian countries, where the knowledge passed down through generations as literally as possible in order to save their authority (Pennycook, 1996). Clearly, the reproduction features of a spoken text are of unquestionable cultural value. Copying is still heavily used during the stages of primary and secondary education, a pedagogically valid practice for learning the use of the written language. Thus, it is much less evident when one can make words borrowed and when not.

Pennycook (1996) traces a long and interesting argument about the ideological implications associated with the intellectual property of written texts. For this author, the notion of a text ownership is complex, since the need to memorize texts is, in most cases, absolutely necessary during the learning of the individual. If a particular text presents ideas that appear to be of wide acceptation and occurrence, it seems questionable to assign ownership of these ideas to the author of that text. Thus, Pennycook (1996) is favorably inclined to the Kearney's concept (mentioned in Pennycook, 1996) that the notion of "author" came in a moment of individualization in the history of ideas, knowledge, literature, philosophy and science. And, therefore, the preparation of texts began to be directly related to the notion of individual ownership, which in turn established notions of authorship, giving rise to new and original text as being characteristic of Western modernity. Literal plagiarism, then, emerged as a result of the concept of authorship individualization. By taking such premises in an uncompromised manner, the teacher suffers from the dilemma of the transmission of other's knowledge through their own words. By accusing students of lack of originality, Pennycook (1996) shows the contradiction of teachers who suffer from the same problem, just repeating a content without having their own production of the teached content. The same author also notes that the rise of electronic media shows a tendency to indicate the death of the authorship and to the textual deconstruction. Citing Scollon (1994), Pennycook (1996) illustrates how the currently dominant utilitarian ideology, with emphasis on the owner's copyright of the text, goes to a more diffuse form of referencing, related to ways of authorship and transmission that are based on oral traditions. The author argues that academic texts are increasingly built upon layers of texts available on the Internet, making the notion of authorship becoming less defined. Thus, to defend the culture of originality, creativity and authorship of a text set, the teachers begin to assume some degree of conceptual incoherence related to the language and its meaning. Pennycook (1996) presents Scollon's opinion (1995), which states that "[...] the traditional view of plagiarism constitutes, in fact, an ideological position which privileges a concept of the person established within the European Enlightenment, and ... as such it obscures our understanding of the construction of identity in intercultural discourse".

There are many forms of plagiarism, considered to be of greater or lesser importance, but extremely common (Pennycook, 1996): for example, the copy of the questions answered by others while students perform tests and examinations, in addition to the classical verbatim copying of texts. Copying paperwork done by other students is, to some extent, an accepted attitude by students in general, and rarely result in a formal complaint. Much worse is the acquisition of monographs, theses and dissertations from companies that sell such manuscripts (Hayes \& Introna, 2005; Macdonald \& Carroll, 2006), of which nothing is known on how such texts have been 
elaborated. Considering that the preparation and writing of paperwork is an essential activity of educational training, the acquisition of such paid work is totally unacceptable and companies that sell them should be prohibited by law from offering such services, as manifested by Paiva (2010) in a document recorded by the National Board of Institutional Relations of the Federal Council of the Brazilian Bar Association.

While plagiarism is commonly assigned to students in general, this practice is not limited to these. Researchers and university professors also make use of plagiarism in the writing of various documents. Such practices must be under survey in the case of these professionals, not only due to the fact itself, but also because teachers and researchers are educators of students and trainees. While self-plagiarism may be considered acceptable to a limited extent, plagiarism should be abolished as much as possible.

Despite the apparently deliberate action of plagiarism, sometimes the intention to plagiarize is not fully characterized due to lack of knowledge of whom is plagiarizing. Considering its variations, according to Maurer et al. (2006) plagiarism can be: "a) accidental: due to lack of plagiarism knowledge, and understanding of citation or referencing style being practiced at an institute; b) Unintentional: the vastness of available information influences thoughts and the same ideas may come out via spoken or written expressions as one's own; d) intentional: a deliberate act of copying complete or part of someone else's work without giving proper credit to original creator; d) self plagiarism: using self published work in some other form without referring to original one".

In addition, there are different ways to plagiarize, such as the direct copying, plagiarism of ideas, to paraphrase (changing the sentence building using the same words meaning, but changing words' ordering within the sentence), non-textual plagiarism, such as in movies making, paintings, sound recording, etc. (Maurer et al., 2006).

In general, it is observed that the importance of plagiarism has significantly increased since 2000, particularly in English speaking countries. Previously the guidelines and procedures for the assessment of plagiarism by higher education institutions were not yet well defined (Macdonald \& Carroll, 2006). A study mentioned by Maurer et al. (2006) revealed that the project of the Center for Academic Integrity Assessment of the U.S. indicated that $40 \%$ of students admitted to have committed plagiarism (2005 data), compared to $10 \%$ in 1999. Maurer et al. (2006) also mentioned another assessment conducted by a professor at Rutgers University in 2003, which showed that 38\% of the assessed students committed plagiarism. The same authors pointed out that in developing countries the concept of plagiarism is less known and is less well defined, and few institutions have clearly defined rules about what is established as plagiarism and penalties on the practice of plagiarism. Indeed, while most higher education institutions of excellence in the US and UK establish guidelines, standards and procedures with respect to plagiarism, very clear and easy to access, in Brazil such guidelines are completely missing. Searches were carried out on the web pages of more than twenty Brazilian higher education institutions and in none of these guidelines and guidance on plagiarism were found, and how it should be detected and its author(s) punished.

By approaching the problem of plagiarism, it is necessary to define what is plagiarism, why plagiarism is wrong, how to prevent plagiarism, how to detect plagiarism and what punitive measures can and should be adopted (Macdonald \& Carroll, 2006). Plagiarism is a rather complex issue, understood differently by students, teachers, education institutions and the media. It is therefore necessary to understand the reasons for plagiarizing, the consequences of plagiarism and the penalties for it, in order to consider why the scope and the many aspects of this issue are so controversial.

\section{Reasons to plagiarize}

Although the term "plagiarism" has a significant cultural influence, its real significance seems rather subjective. In addition to the fact that the notion of plagiarism vary with the culture in which this concept is considered, the intrinsic knowledge of its significance is not of a consensus. For example, many times it seems that literal copying of a single phrase or a short piece of text is perfectly acceptable, provided the primary literature source is cited (Macdonald \& Carroll, 2006). Even textual creation is extensively based on previously written texts, in order to build concepts, reasoning and argumentative information. Taking also into account the electronic resources available on the Internet, intertextuality has assumed significant proportions, with difficult limitations to be established.

Plagiarism can also be seen as a resistance movement to the current Western cultural model, which values the extreme individuality, creativity and originality, putting aside the creation from another building, without definitions of ownership or authorship (Pennycook, 1996).

Very often students do not know the actual notion of plagiarism, nor the consequences of it, due to failures in their training. In fact, questioning undergraduate and graduate students of the Institute of Chemistry at São Carlos (University of São Paulo) if at some point in their training they had any lecture, class or 
explanation on plagiarism and its consequences, all said no. Students are supposed to be capable to write original texts, repeatedly and continuously during their training, particularly in the preparation of monographs, as well as of dissertations and doctoral theses, abstracts and condensed texts for presentation at scientific meetings, as well as articles for publication. Not knowing what is established as being plagiarism in all its peculiarities, students are subject to plagiarize, deliberately or not. Thus, an orientation by higher education institutions and by teachers/researchers about plagiarism becomes absolutely necessary.

In assessing the reasons why plagiarism is committed, Pennycook (1996) notes that power relations established between teachers and students should be continuously evaluated in order to investigate the influence on the quality of education, whether stimulating or deleterious to original and innovative textual creation. Considering that the current system of education requires that students should frequently repeat pre-established ideas in the same way that teachers in the classroom, it becomes necessary to establish educational programs that can properly prepare students to face such situations when they arise (Pennycook, 1996). Other authors consider relevant comprehensive and holistic actions for the assessment plagiarism issues, taking into account educational approaches and training of individuals who must build their own texts (Macdonald \& Carroll, 2006). To this purpose, students must acquire very good skills to write texts, a rare educational practice in the current conditions of Brazilian education.

Also observed is that an increase in the level of assessments leads to an increase in cases of plagiarism related to them (Macdonald \& Carroll, 2006). This is due, in large part, to the fact that, under such circumstances there is a decreased availability of study time for students and, in parallel, an increase in the use of simplistic learning tools. Consequently, the student seems to be forced to adopt a pragmatic inappropriate targeting, aiming to only obtain sufficient marks to be approved and get the desired degree, which leads sometimes to commit plagiarism. In parallel, students, aware of the fact that teachers also have very limited time to read and to an in depth analysis of texts that should be assessed, assume that plagiarism can take place, albeit to a limited extent, because this is unlikely to be detected. Hence the need for improvement of students learning, which should include how to take notes during educational activities, the sparing use of paraphrase and knowledge of proper use of citations and references.

In most cases the blame is solely assigned to the student for misconduct or malice, and not to the institution that has not provided adequate training to the students to prepare texts, to develop critical textual analysis, to improve their creativity and take responsibility for any statements they have to present as their own. Thus, according to Macdonald \& Carroll, (2006), it is up to institutions of higher education:

a) to prepare students for their learning tasks, or show them how necessary is to learn and assimilate the knowledge that they are offered;

b) to establish programs and teaching methods that minimize the possibility of student plagiarism, such as memorization, repetition and reproduction in excess; c) to develop programs to prevent plagiarism rather than to apply punitive policies, though these are necessary.

By sharing responsibilities between students, teachers and institutions, it is clear the benefit to the learning system, which will enable the student to acquire knowledge on how important is the ability to create new texts from various references. It is absolutely essential to establish programs of discussion sessions between teachers and students about academic integrity, the nature of the assessments, the value of the acquisition and application of critical analysis and elaboration of the original texts. Institutions and their professionals have a responsibility to contribute to the education of students and, therefore, students must be informed at an early age about what constitutes plagiarism and the consequences of plagiarizing.

\section{The consequences of the plagiarizing act}

The student must not only learn how to avoid plagiarism, but also why should avoid it (Macdonald \& Carroll, 2006). Therefore, it is also necessary for the educator, as a professor, a researcher, and even members of institutional technical support, be prepared, informed and convinced of the risks we are subjected when plagiarism is used.

The main consequences of plagiarism are penalties that can range from warnings to various forms of legal sanctions. While consensus on how, when and the way to apply such sanctions is nearly nonexistent, the consensus in applying sanctions is definitely absolute. Plagiarism is viewed as an extremely negative attitude, even when performed in a very slight extent. Because it is considered as unacceptable, the word has a very negative weight. Especially when plagiarism is detected in academia. It is interesting to note that the media and society in general rarely discuss and deny plagiarism committed with books published by different publishers, although this type of plagiarism is very recurrent, as evidenced by the blog I do not like plagiarism, by Denise Bottmann (Bottmann, 2011).

The penalties resulting from sanctions may vary in nature. In the case of academic plagiarism, i.e., when committed within higher education institutions, 
penalties can include: assigning a 0 (zero) score to a question a student has copied from another, or even an exam that the student copied, or a written paperwork that was the result of copying parts or in its entirety from the other(s); failure in courses if the student has repeatedly copied texts and issues submitted for review; suspension of student activities during certain periods when it turns out that the student may have committed plagiarism of a more serious nature; in the case of the preparation of monographs, MSc dissertations and $\mathrm{PhD}$ theses, the observation of plagiarism in small portions may lead evaluators to require a new writing and resubmission of the work; in the case of plagiarism noted in extensive writings, the student enrolement may be finished (Wagner, 2011).

In the case of teachers and researchers, plagiarism in scientific studies can result in many different sanctions: warning, public apology, suspension of its activities for a specified period and even dismissal. The consequences in these cases can be a profound loss to the career of professionals, who can be literally annihilated.

But the main consequence of plagiarism seems to be a deep personal frustration and demoralization on the part of whom commits it (Wagner, 2011). Pennycook (1996) considers that Western modernity has established that the words' borrowing from creative and innovative authors is a crime against individual property rights. Citing Kolich, Pennycook (1996) mentions that plagiarism is "[...] "is a highly emotional subject, and the issue of how to deal with it seems muddled by moral confusion, apprehension, and general loathing." Although, according to Pennycook (1996), the notion of individualism is very well established, such an assumption should not justify the moral outrage and the exarcebated way that plagiarists are persecuted.

Society sees the plagiarist as a criminal, often relentlessly, even if the plagiarist has committed plagiarism in a very short extension, possibly unintentional, and for the first time. The word plagiarism entails a strong dislike, perhaps disgust, making a plagiarist an unworthy individual. Although this view can easily be considered as being exaggerated, it is so strongly entrenched that it would require a process of reeducation of society as a whole to show that there are different forms of plagiarism, and that almost all people have plagiarized one day.

\section{Punishments for the academic plagiarism}

Punishments for academic plagiarism can occur at two levels: at the teacher-student relationship and at the student-institution relationship. In general punishments established by teachers tend to be softer, without, however, this tendency being a rule. In general, punishment by teachers are verbal or written warnings, or by change marks or the final evaluation of a student course or activity. Institutional sanctions may include reprimands, education for learning academic integrity, social work, suspension, expulsion, revocation of the title(s) granted(s) and even legal penalties, in accordance with current legislation (Maurer et al., 2006). Different universities in North America and Europe have adopted different procedures as punishment for various forms of plagiarism, in view of the increasing numbers of occurrence of such cases. Stanford University, for instance, saw an increase in cases of intra-institutional plagiarism of $126 \%$ between 1998 and 2001, for which the most common punishment was suspension during a fourth of the school period and 40 hours of community service (Maurer et al., 2006). The University of Yale adopts punishments ranging from reprimands to suspensions. In the case of University of California at Berkeley, the institution encourages the resolution of problems of plagiarism directly between teacher and student, and the punishments are more commonly applied as notes of warning or censure, community service, submit a letter of apology, additional assessment activities, disciplinary failure, suspension, among others (Maurer et al., 2006).

In order to establish and apply penalties against plagiarism, it is first necessary to define what is considered plagiarism from a technical standpoint. Macdonald \& Carroll (2006) suggest that the characterization of plagiarism should include the analysis and documentation of how this was detected and analyzed, taking into account:

1. The extent to which it was committed: the written work was plagiarized (a sentence, paragraph, entire sections all work)? Was a whole text section plagiarized, such as introduction, methods, discussion or conclusion?

2. The level of student: a beginner or are already in advanced level?

3. Knowledge of institutional rules and norms by the student: the student was warned about the importance of not plagiarizing, his responsibility when citing and bibliographic referencing? A student committed plagiarism for the first time or did it before? In the case of foreign students, were they notified about the customs, rules and guidelines of the institution to which they are enrolled?

4. The disciplinary rules adopted by the institution.

It is observed that there are two well defined trends to establish punishments for plagiarism. The first establish peremptory penalties to any type of plagiarism. This way of approaching the plagiarism problem, considered traditional and conservative, is imbued with the notion of authority by those who recognize and identify plagiarism, often in a teacherstudent relationship, in that the latter must follow strict 
guidelines and standards concerning the preparation of texts (Macdonald \& Carroll, 2006). By adopting such an approach to identify and punish plagiarism, pure and simply, everyone loses, because there is no intellectual, moral and ethical growth. Such punishment penalizes, sometimes irreversibly, the one who broke the rules, in many different ways, as noted above. It presents the risk of excessive penalizing, sometimes very unfairly. The second way to punish plagiarism search not only to penalize the plagiarist, but also looks toward a re-educational approach, in order to minimize demoralization and to show that plagiarism does not benefit (quite the contrary), but the undermines both the act itself and by the use of plagiarism as a common practice.

Delegating the responsibility for penalties to individuals who detect plagiarism, often the teacher, may be even worse. The teacher must not be responsible to determine the punishment because he is not the institutional element who establishes policies. When this responsibility is assigned to the teacher, the inadequacy of the punishment, and sometimes the misunderstanding of how to tackle the problem, become apparent. It is to the institution the responsibility to establish such policies, aiming to avoid differential punishments in different situations that require a detailed analysis of the facts (Macdonald \& Carroll, 2006).

The Academic Conduct Officers (ACO) from Oxford Brookes University suggests the following measures when one observes the occurrence of plagiarism (Macdonald \& Carroll, 2006):

"1. A recorded discussion, which should also take into account the institutional support to the student;

2. Score(s) reduction(s) in paperwork in which the plagiarism occurred, depending on the extent of it.

3. Resubmission of work originally plagiarized by the student;

4. Zero score if the work has been wholly plagiarized;

5. Zero score for the entire course if the extent of plagiarism is even more significant."

Penalties should be more severely examined by a committee under the specific circumstances that may arise. In applying such guidelines, the ACO went on to acquire more knowledge and experience of dealing with plagiarism problems, which were addressed and faced more professionally. Annual assessments used to evaluate the extent of plagiarism are currently adopted by the Oxford Brookes University. The same institution has established the following guidelines to minimize the occurrence of plagiarism by their students (Macdonald \& Carroll, 2006):

1. Check if to the students were taught ways to acquire original writing abilities, according to their needs;

2. Check if policies were properly communicated to students so that they can ensure their academic integrity and assume their responsibilities;

3. Observe the importance the institution attaches to academic integrity;

4. Promote activities with the faculty guidance for teachers in order to avoid plagiarism, to know the procedures and regulations to be adopted, on how to properly prepare the courses to be taught in order to avoid plagiarism, as well as detecting and responsibilities when detection of plagiarism;

5. To make aware that it is not to the faculty staff to establish punitive sanctions aiming to avoid inconsistent and unfair treatment;

6. Build a systematic approach for obtaining data that indicate the occurrence of plagiarism;

7. Preparation of statistical tables that show overall numbers of cases of plagiarism and how these were addressed and resolved.

To determine punishments for plagiarism can be at the same time a difficult and embarrassing activity. Especially in the case of not knowing the actual circumstances that led to the plagiarist plagiarize, and if the plagiarism was intentional or not. Thus, establishing punishments for plagiarism should be considered with great care and professionalism.

\section{Conclusion}

Plagiarism is a complex concept related to the cultural construction of human identity (Pennycook, 1996). The concept of plagiarism should be understood in its historical and cultural context, and with respect to cultural alternatives.

While some authors consider that the cultural inclusion of students in the academic context is of paramount importance to make them understand how to establish the universe of knowledge in learning and work (Macdonald \& Carroll, 2006), others point out that this argument is inappropriate, since such assumptions only indicate that students must accept a normative view of the so-called academic standards, and how this system works. This, in turn, fails to take into consideration the complexity of factors involved in the drafting of texts. Consequently, the way plagiarism is commonly referred to would be pedagogically questionable and intellectually arrogant (Pennycook, 1996).

While plagiarism is mainly deployed in academia, is not restricted, however, to it. There is plagiarism in high school education, both by students and by teachers, and it has been detected in government agencies and public institutions as well. When services of companies that offer the drafting of documents, monographs, theses and dissertations, among others, are hired, many of these companies make extensive use of plagiarism in documents they offer to customers (Maurer at al., 2006). 
Teachers have to discuss with students how the concepts of citation, paraphrasing and textual loan were built, and how the notions of authorship, authenticity and authority were simultaneously established (Pennycook, 1996). However, firstly it is necessary to provide to students and academic professionals conditions to understand and develop skills to avoid plagiarism (Macdonald \& Carroll, 2006). The establishment, implementation and dissemination of well-defined regulations are essential to good academic conduct. Developing techniques and assessment methods that minimize the occurrence of plagiarism are very intelligent pedagogical alternatives. The approach to the problem of plagiarism in academia should be viewed comprehensively, aiming to integrate the activities carried out by students, professors and researchers. Plagiarism should be discussed in connection with these activities, so that all are aware how important are good writing practices, without, however, forgetting to realize that literal copying, or modify text fragments of general character, for which an authorship and ownership is absent, may be acceptable if carried out to a very limited extent. Taking into account that the learning of language is to some extent the use of others' words, it is worthy to consider being flexible and not dogmatic when establishing acceptable limits of borrowing words.

Although academic institutions are increasingly better equipped with specific software to survey plagiarism (Maurer et al., 2006), the elimination of such practices is not only a result of its detection and punishment. It must includes a review of educational programs that can promote the enhancement of creativity and originality, rather than copy. Educators must be prepared to recognize the limitations of using written language as a form of expression, and to recognize that intertextuality can serve as a useful tool, provided it is used with discretion and wisdom. Institutions need to foster a creative environment, and application of appropriate methodologies for assessment, so that the elements participating in the academic life will enjoy the many benefits that result from these activities. The improvement of learning, knowledge and good academic practices, instead of focusing on potential problems and directing institutional efforts towards the detection and punishment of plagiarism, are the result of an ongoing work promote education, of which the entire society will be beneficiary.

\section{References}

Anonymous 2009a. A polêmica do plágio entre mestres e doutores. JC e-mail 3876, de 26 de Outubro de 2009. Available at: <http://www.jornaldaciencia.org.br/ Detalhe.jsp?id=66860>. Acessed in 6 Apr 2011.
Anonymous 2009b. Pesquisadora que violou direitos autorais indenizará vítima de plágio. <http://www.jusbrasil. com.br/noticias/1107616/pesquisadora-que-violoudireitos-autorais-indenizara-vitima-de-plagio $>$. Acessed in 6 Apr 2011.

Anonymous 2011. Aumento do plágio em produções científicas preocupa pesquisadores em todo o mundo. O Estado de S. Paulo, 16 de março de 2011. Available at: < http://www.estadao.com.br/noticias/ vidae, aumento-do-plagio-em-producoes-cientificaspreocupa-pesquisadores-em-todo-o-mundo,692874,0. htm>. Acessed in 06 abr. 2011.

Bottmann D 2011. Não gosto de plágio. Available at: $<$ http:// naogostodeplagio.blogspot.com/>. Acessed in $6 \mathrm{Apr}$ 2011.

Butler D 2010. Journals step up plagiarism policing. Nature 466: 167, doi:10.1038/466167a <http://www.nature. com/news/2010/100705/full/466167a.html>. Acessed in 5 May 2011.

CAPES 2011. Orientações Capes - Combate ao plágio. Available at: <http://www.unesp.br/cgb/mostra_arq_ multi.php?arquivo=7602>. Acessed in 6 Apr 2011.

Dallago RM, Baibich IM, Gigola C 2005. Catalisador Pd $/ \gamma$ $\mathrm{Al}_{2} \mathrm{O}_{3}$ : efeito do tamanho de partícula na atividade catalítica para combustão do $\mathrm{CH}_{4}$. Quim Nova 28: 952-956.

Garcia R 2008. USP condena físicos acusados de plágio. Folha de S. Paulo, 24 Jul 2008. Available at: <http://www1. folha.uol.com.br/folha/ciencia/ult306u448257. shtml>. Acessed in 6 Apr 2011.

Garcia, R 2009. Periódico científico publica dois estudos plagiados na íntegra. Folha de S. Paulo, 7 Maio 2009. Available at: <http://www1.folha.uol.com.br/folha/ ciencia/ult306u561841.shtml>. Acessed in May 19, 2011.

Hayes N, Introna LD 2005. Cultural values, plagiarism, and fairness: when plagiarism gets in the way of learning. Ethics Behav 15: 213-231.

Küchler IL, Silva FAM 1999. Método potenciométrico para determinação de cobre em cachaça. Quim Nova 2: 339-341.

Macdonald R, Carroll J 2006. Plagiarism - a complex issue requiring a holistic institutional approach. Assess Eval High Educ 31: 233-245.

Maurer H, Kappe F, Zaka B 2006. Plagiarism - a survey. J Univ Comp Sci 12: 1050-1084.

Paiva RB 2010. Documento apresentado ao Presidente do Conselho Federal da Ordem dos Advogados do Brasil - Ophir Cavalcante Júnior. Available at: < http:// www.oab.org.br/combateplagio/CombatePlagio.pdf $>$. Acessed in 6 Apr 2011.

Pennycook A 1996. Borrowing others' words: text, ownership, memory, and plagiarism. TESOL Quart 30: 201-230.

Rodrigues, G 2008. É proibido colar. Available at: <http:// www.jornaldaciencia.org.br/Detalhe.jsp?id=59193>. 
Acessed in 19 May 2011.

Scollon R 1994. As a matter of fact: The changing ideology of authorship and responsibility in discourse. World Engl 13: 33-46.

Scollon R 1995. Plagiarism and ideology: Identity in intercultural discourse. Language Soc 24: 1-28.

Skandalakis JE, Mirilas P 2004. Plagiarism. Arch Surg 139: 1022-1024.

Stanisci C 2011. Promotor admite plágio em concurso. $O$ Estado de S. Paulo, 17 Feb 2011. Available at: <http:// www.estadao.com.br/estadaodehoje/20110217/not imp680600,0.php>. Acessed in 6 Apr 2011.
Wagner NR 2011. Plagiarism by student programmers. Available at: http://citeseerx.ist.psu.edu/viewdoc/do wnload?doi=10.1.1.140.2023\&rep=rep $1 \&$ type $=$ pdf. Acessed in 6 Apr 2011.

\section{*Correspondence}

Instituto de Química de São Carlos, Universidade de São Paulo

Caixa Postal 780, 13560-970, São Carlos, SP - Brazil rgsberlinck@iqsc.usp.br

Tel. +551633739954 